Journal of Islamic Medicine

Volume 2 (1) (2018), Pages 50-57

\title{
Terapi dengan Dinydroartemisinin Piperaquine (DHP) dapat Mencegah Terjadinya Anemia Tetapi Tidak Dapat Mencegah IUGR pada Mencit Bunting yang di Infeksi Plasmodium berghei
}

\author{
Diah Andriana ${ }^{1}$ \\ Email : andriana_2209yahoo.com \\ ${ }^{1}$ Laboratorium Klinik Fakultas Kedokteran Universitas Islam Malang
}

\begin{abstract}
Infection of malaria with Plasmodium falciparum during pregnancy is associated with infection in the placenta and extensive adverse effects on the mother and the fetus it contains include one of them anemia in pregnant women while in the fetus IUGR occurs. Eighteen pregnant mice which were infected with Plasmodium berghei were divided into 2 groups, namely the control group and the treatment group treated with DHP. Mice are surgically removed after the 18th day after infection. Anemia was examined by looking at $\mathrm{Hb}$ and IUGR checked by testing the fetus. The results were found that DHP therapy in pregnant mice in Plasmodium berghei infection can prevent anemia $\left(\mathrm{t}_{\text {coun }} \mathrm{t}=1.45 \geq \mathrm{tt}_{\text {able }}=1.96\right)$ but cannot prevent the occurrence of IUGR $\left(\mathrm{t}_{\text {coun }}=\right.$ $\left.1.90 \geq t_{\text {table }}=1.96\right)$. Conclusion DHP therapy in mice with Plasmodium berghei infection can prevent anemia but can cause the fetus to experience IUGR.
\end{abstract}

\begin{abstract}
ABSTRAK
Infeksi malaria dengan Plasmodium falciparum selama kehamilan berhubungan dengan infeksi pada plasenta dan dampak buruk yang luas pada ibu maupun janin yang dikandungnya meliputi salah satunya anemia pada ibu hamil sedangkan pada janin terjadinya IUGR. Delapan belas mencit bunting yang di infeksi Plasmodium berghei di bagi menjadi 2 kelompok yaitu kelompok kontrol dan kelompok perlakuan yang diterapi DHP. Mencit di bedah setelah hari ke 18 paska infeksi. Anemia di periksa dengan melihat Hb dan IUGR di periksa dengan meninbang janin. Hasil di dapatkan bahwa terapi DHP pada mencit bunting yang di infeksi Plasmodium berghei dapat mencegah terjadinya anemia $\left(\mathrm{t}_{\text {hitung }}=1,45 \geq \mathrm{tt}_{\text {abel }}=1,96\right)$ tetapi tidak dapat mencegah terjadinya IUGR $\left(t_{\text {hitung }}=1,90 \geq t_{\text {tabel }}=1,96\right)$. Kesimpulan terapi DHP pada mencit yang di infeksi Plasmodium berghei dapat mencegah terjadinya anemia tetapi dapat menyebabkan janin mengalami IUGR.
\end{abstract}

Kata kunci : Plasmodium berghei, DHP, Anemia, IUGR

Corresponding author :

* Diah Andriana

Laboratorium Klinik Fakultas Kedokteran Universitas Islam Malang 


\section{PENDAHULUAN}

Infeksi malaria sampai saat ini masih merupakan problem klinik di negara-negara berkembang terutama negara yang beriklim tropik, termasuk Indonesia. Di Indonesia penyakit malaria masih merupakan penyakit infeksi utama di kawasan Indonesia bagian Timur. Infeksi ini dapat menyerang semua masyarakat dari segala golongan, termasuk golongan yang paling rentan seperti wanita hamil (1).

Infeksi malaria pada kehamilan sangat merugikan baik bagi ibu dan janin yang dikandungnya, karena infeksi ini dapat meningkatkan kejadian morbiditas dan mortalitas ibu maupun janin. Pada ibu menyebabkan anemia, malaria serebral, edema paru, gagal ginjal bahkan dapat menyebabkan kematian. Pada janin menyebabkan abortus, persainan prematur, berat badan lahir rendah, dan kematian janin. Infeksi pada wanita hamil oleh parasit malaria ini sangat mudah terjadi, hal ini disebabkan oleh adanya perubahan sistim imunitas ibu selama kehamilan, baik imunitas seluler maupun imunitas humoral, serta diduga juga sebagai akibat peningkatan horman kortisol. Pada wanita selama kehamilan terinfeksi malaria risiko terjadinya anemia sebesar (3-15\%), berat badan lahir rendah (13-70\%) dan kematian neonatal (3- 8\%) (3). Infeksi malaria pada ibu hamil dapat menyebabkan anemia, splenomegali, Hipoglikemia, infeksi plasenta, malaria selebral sedangkan pada janin menyebabkan kematian janin dalam kandungan, abortus, kelahiran prematur, berat badan lahir rendah dan malaria kongenital (4).

Semua spesies Plasmodium dapat menginfeksi ibu hamil, akan tetapi yang paling banyak diketahui pengaruhnya dalam kehamilan adalah Plasmodium vivax dan Plasmodium falciparum lebi sering dijumpai di area tranmisi tinggi malaria, sedangkan infeksi Plasmodium vivax lebih sering di area tranmisi tinggi malaria. Terdapat perbedaan patogenesis malaria dalam kehamilan antara yang di sebabkan Plasmodium vivax dan Plasmodium falciparum. Plasmodium vivax menginfeksi retikulosit setelah terikat pada merozoit melalui Duffy antigen receptor. Infeksi Plasmodium vivax pada eritrosit tidak menyebabkan ekspresi protein permukaan eritrosit sehingga eritrosit tidak melakukan sekuestrasi (5). Protein permukaan eritrosit yang di ekspresikan setelah infeksi Plasmodium falciparum menyebabkan eritrosit melakukan sekuestrasi pada ruang intervilous plasenta sehingga terjadi parasitemia plasenta yang tinggi (6).

Obat DHP untuk malaria salah satunya mengandung artemisin. Artemisinin (ART) adalah zat yang dihasilkan oleh tanaman Artemisia annua yang telah digunakan sejak lama sebagai obat demam dan malaria (7). ART termasuk dalam golongan obat antimalaria kelompok seskuiter penlakton. ART merupakan salah satu obat pilihan pada terapi malaria karena memiliki kelebihan yaitu mudah diabsorbsi, aman, dan cepat diubah menjadi bentuk metabolit aktif. Walaupun demikian, ART memiliki kelemahan karena tidak bisa digunakan secara monoterapi tapi harus dikombinasikan dengan obat antimalaria lainnya. Kombinasi artemisinin dengan obatobat malaria yang tersedia di Indonesia sudah ada (8).

\section{Tinjauan Pustaka}

Malaria di sebabkan oleh Plasmodium. Genus Plasmodium terdiri dari sekitar 200 spesies dan sampai dengan tahun 2004 masih dikenal ada lima spesies yang dapat menginfeksi manusia, yaitu Plasmodium falciparum, Plasmodium vivax, Plasmodium malariae, Plasmodium ovale dan Plasmodium malaria (9,10). Pada tahun 1965 penelitian di Asia Tenggara menunjukkan Plasmodium knowlesi sebagai agen etiologi kelima yang berpotensi menginfeksi manusia dan dapat menyebabkan manifestasi klinis yang berat. Plasmodium knowlesi merupakan parasit 
malaria yang inang alaminya adalah kera jenis macacau, yaitu Macaca fascicularis, $M$. nemestina, M.inus, dan Saimiri scirea (11).

Secara teori kejadian malaria pada kehamilan di pengaruhi oleh tingkat tranmisi dan jumlah paritas. Telah banyak dilaporkan primigravida dan secundi-gravida memiliki resiko tertinggi walaupun resiko juga terjadi pada multigravida. Primigravida mempunyai prevalensi malaria kehamilan lebih tinggi daripada multigravida dan mempunyai dampak fatal pada bayinya. Serum dari multigravida dapat mengaglutinasi parasit dari plasenta, hal ini tidak terjadi jika yang di gunakan adalah serum primigravida. Ini membuktikan bahwa isolat tidak terjadi sebelum kehamilan tetapi respon imun spesifik berupa antibodi terhadap varian ini berkembang setelah paparan selama kehamilan (12). Antibodi terhadap parasit plasenta berhubungan dengan penurunan parasitemia plasenta dan peningkatan berat lahir dan umur kelahiran. Antibodi maternal berhubungan dengan kadar hemoglobin maternal dan juga berat badan lahir. Hal ini mendorong strategi penemuan vaksin untuk malaria kehamilan dan menjadikan berat badan lahir dapat di gunakan sebagai indikator efikasi vaksin tersebut pada uji klinik (13).

\section{Metodelogi Penelitian \\ Rancangan Penelitian}

Penelitian ini merupakan penelitian eksperimental murni yang dikerjakan di laboratorium secara in vivo dengan membandingkan hasil yang didapat pada mencit bunting yang terinfeksi malaria kemudian diterapi DHP dengan kelompok kontrol.

\section{Tempat dan Waktu Penelitian}

Penelitian dilakukan di Laboratorium Parasitologi, Fakultas Brawijaya Waktu percobaan dilaksanakan tahun 2018.

\section{Alat dan Bahan Penelitian \\ Perawatan Mencit}

Alat perawatan mencit; kandang mencit masing-masing untuk 5 ekor mencit, botol minum mencit. Bahan; makanan mencit (BR1 pakanan olahan ternak untuk memenuhi kecukupan nutrisi mencit dan kecambah kacang hijau, sekam.

\section{Inokulasi Plasmodium berghei}

Alat untuk inokulasi; tabung eppendof, mikropipet, hemositometer, gelas obyek, tip kuning, tabung falcon $15 \mathrm{ml}$, gunting steril, dan spuit insulin $1 \mathrm{ml}$, mikroskop. Bahan; Plasmodium berghei dari darah mencit terinfeksi, larutan Phosphate Buffer Saline (PBS), larutan $\mathrm{M}^{+}$, Ethylene Diamine Tetra Acetic Acid (EDTA), methanol p.a, kapas alkohol, bufer giemsa dan larutan Giemsa.

\section{Pengukuran Derajat Parasitemia dan Jumlah Eritrosit}

Alat pengukuran derajat parasitemia dan jumlah eritrosit; tabung eppendof, mikropipet, hemositometer,tip kuning, gelas preparat, gunting steril, pipet, mikroskop. Bahan; Phosphate Buffer Saline (PBS), kapas alkohol, bufer giemsa \& larutan giemsa, methanol p.a, minyak emersi.

\section{Sampel Mencit}


Mencit diperoleh dari Unit Pengembangan Hewan Percobaan Universitas Gadjah Mada.

\section{Pembuntingan Mencit}

Pembuntingan mencit betina sebanyak 36 ekor dilakukan setelah persiapan sinkronisasi estrus melalui tiga tahap, yaitu Leeboot effect, Pheromon effect dan Whiten effect (14).

\section{Pengukuran Anemia}

Pemeriksaan Anemia di lakukan di Laboratorium.

\section{Pengukuran Berat Janin}

Gangguan perkembangan janin diukur melalui penimbangan berat badan janin Penimbangan berat badan janin dilakukan setelah pembedahan yaitu pada hari ke-18 setelah perkawinan. Janin di pisahkan dengan plasenta dan dibersihkan selaput lendirnya, selanjutnya di timbang satu persatu dengan menggunakan neraca analitis Mettler AE 50 dengan satuan ukuran gram.

\section{Analisis Data}

Analisis data menggunakan uji t berpasangan dan analisis Structur Equation Modeling (SEM).

\section{HASIL}

Analisis penelitian ini menggunakan SEM (Struktur Ekuivalen Modelling) di dapatkan hasil sebagai berikut :

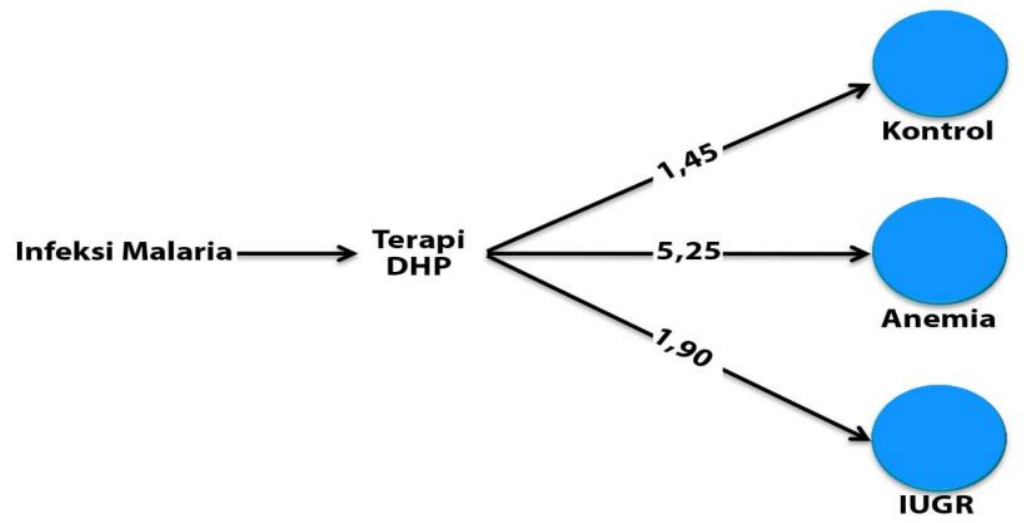

Gambar 1. Model Struktural Equation Modeling (SEM) untuk Menentukan Siknifikansi Hubungan Dinydroartemisinin Piperaquine (DHP) dengan Anemia dan IUGR.

Penelitian ini menetapkan interval kepercayaan 95\% atau $\mathrm{p}=0,05$, yang berarti hasil signifikan diperoleh ketika nilai yang dihitung $t \geq 1,96$. Pada kelompok kontrol analisis statistik menunjukkan bahwa Plasmodium berghei dapat menyebabkan anemia pada mencit bunting $\left(\mathrm{t}_{\text {hitung }}=1,45 \geq \mathrm{t}_{\text {tabel }}=1,96\right)$, sedangkan pada kelompok perlakuan yaitu yang di terapi dengan DHP mencit bunting yang di infeksi Plasmodium berghei tidak menyebabkan anemia $\left.\mathrm{t}_{\text {hitung }}=1,45 \geq \mathrm{t}_{\text {tabel }}=1,96\right)$ tetapi terapi DHP menyebabkan IUGR pada mencit bunting yang di infeksi Plasmodium berghei $\left(\mathrm{t}_{\mathrm{hitung}}=1,90 \geq \mathrm{t}_{\text {tabel }}=1,96\right)$. 


\section{PEMBAHASAN}

Menurut defenisi WHO, anemia pada kehamilan adalah bila kadar haemoglobin $(\mathrm{Hb})<11 \mathrm{~g} / \mathrm{dl}$. Gregor (15) mendapatkan data bahwa penurunan kadar $\mathrm{Hb}$ dalam darah hubungannya dengan parasitemia, terbesar terjadi pada primigravida dan berkurang sesuai dengan penyusunan peningkatan paritas (16). Van Dongen (1983) melaporkan bahwa di Zambia, primigravida dengan infeksi P. falciparum merupakan kelompokyang beresiko tinggi menderita anemia dibandingkan dengan multigravida (17). Di Nigeria Fleming (1984) melaporkan bahwa malaria sebagai penyebab anemia ditemukan pada $40 \%$ penderita anemia primigravida (18). Anemia pada malaria terjadi karena lisis sel darah merah yang mengandung parasit. Hubungan antara anemia dan splenomegali dilaporkan oleh Brabin (19) yang melakukan penelitian pada wanita hamil di Papua Neu Geuinea, dan menyatakan bahwa makin besar ukuran limpa makin rendah nilai Hb-nya (20). Pada penelitian yang sama Brabin melaporkan hubungan BBLR (berat badan lahir rendah) dan anemia berat pada primigravida. Ternyata anemia yang terjadi pada trimester I kehamilan, sangat menentukan apakah wanita tersebut akan melahirkan bayi dengan berat badan rendah atau tidak karena kecepatan pertumbuhan maksimal janin terjadi sebelum minggu ke 20 usia kehamilan (21)

Pada penelitian ini pada mencit bunting yang di infeksi palsmodium berghei setelah di terapi DHP tidak mengalami anemia tetapi tidak dapat mencegah terjadinya IUGR. Hal ini disebabkan karena terapi DHP mengandung artemisin dan chloroquin. Artemisinin diketahui mempunyai struktur molekul yang mengandung jembatan peroksida (peroxide bridge), mekanisme kerja Artemisinin menurunkan derajat parasit sangat berkaitan dengan struktur molekulnya yang pada proses digesti haemoglobin diputus oleh ion $\mathrm{Fe} 2+$ menjadi radikal bebas yang sangat reaktif. Radikal-radikal Artemisinin ini kemudian menghambat dan memodifikasi berbagai macam molekul dalam Plasmodium yang mengakibatkan Plasmodium tersebut mati $(22,23)$. Penelitian lain menjelaskan mekanisme kerja Artemisinin melalui penghambatan enzim the malarial calsium-dependent ATP ase (PfATP6) yang terletak dalam kompartemen intrasel terbungkus membran yang disebut retikulum endoplasma. Pada Plasmodium, kompartemen ini tersebar luas dalam sitoplasma di luar food vacuole. Radikal bebas yang dihasilkan Artemisinin mengikat dan menghambat PfATP6 secara ireversibel dan spesifik sehingga mengakibatkan pertumbuhan parasit terhambat. (24). selain itu Chloroquine berikatan dengan heme yang akan menghambat pembentukan hemozoin, sehingga heme tetap terakumulasi dalam bentuk free heme yang bersifat toksik dan mengakibatkan kematian Plasmodium $(25,26)$.

\section{DAFTAR PUSTAKA}

1. Tambajong EH. 2000. Patobiologi Malaria. Dalam:Harijanto PN, eds. Ma-laria: Epidemiologi, Patoge-nesis, Manifestasi Klinis.

2. Menendez C. Malaria During Pregnancy : A Priority Area of Malaria Research and Control. Parasitology Today. 1995. May. Vol. 11 No. 5 (119) 178-183.

3. Desai M., Oiter Kuile F.O. Nosten F., McGready R., Asamoa K., Brabin B. 2007. Epidemiology and Burdan of Malaria in Pregnancy. Lancet Infect Dis. 7(2): 93-104. 
4. Rogerson S.j., Mwapasa V., Meshnick S.R., 2007. Malarin In Pregnancy: Linking Immunicity and Pathogenesis to Prevention . Am J Trop Med Hyg. 77(6 Suppl): 14-22.

5. Peters W, Lin 1, Robinson BL \& Walrust DC. The Chemotherapy Of Rodent Malaria, XL. The Action Of Artemisinin And Related Seswuiterpenes. Annals of Tropical Medicine and Parasitology; 1996; 80, 483-489.

6. Pandey AV and Chauhan VS. Heme Polymerization by Malarial Parasit: A Potensial Target For Antimalarial Drug Development. India: International Centre for Genetic Engineering and Biotechnology; 2000.

7. Guyatt H.L and Snow R.W.2004. Impact of malaria During Pregnancy on Low Birth Weight in Sub Sahara Africa. Clin Micrrobial Rev. 17(4): 760-769.

8. Khosla P, Bhanwra S, Singh J, Seth S and Srivastava RK. A Study Of Hypoglycaemic Effect Of A.Indica (Neem) In Normal And Alloxan Diabetic Rabbits. Indian Journal Physiol.Pharmacol; 2000; 44: 69-74.

9. Steketee C.J., Nahlen B.L., Parise M.E., Menendez C. 2001. The Burden of Malaria in Pregnancy and in Malaria-Endemic Areas. Am j Trop Med Hyg. 64(1-2Suppl):28-35.

10. Miller 1.H., Baruch D.I., Marsh K., Doumbo O.K. 2002. The Pathogenic Basic of Malaria. Nature. 415 (6872):673-679.

11. Healer J., McGuinnes D., Carter R., Riley E. 1999. Transmission Blocking Immunity to Plasmodium falciparum in Malaria-Immune Individiuals is associated with Antibodies to The Gamete Surface Protein Pfs230.Parasitolgy. 119(Pt5):425-433.

12. Brabin B. J. An Analysis of Malaria in Pregnancy in africa Bulletin WHO. 1983 61(6) : 1005-1016.

13. Duffy P.E and Fried M. 2003. Antibodies that Inhibit Plasmodium falciparum Adhesion to Chondroitin Sulfate A Are Associated with Increased Birth weight and The Gestational Age of Newborns. Infect Immun. 71(11): 6620-6623.

14. Sardjono, 2007. Pengaruh Infeksi Toxoplasma pada Hasil Kehamilan Melalui Interferongama (IFN- $\gamma$ ), Aktivitas Caspase 3 dan Apoptosis Sel-Sel Plasenta. Library. UNAIR.

15. Cardoso M. A ; M. U Ferreria ; L. M Camargo and S. C Szarfac Anemia, Iron Deficiency and malaria in A rural Community in Brazilian Amazon. Europe J. Clinical Nutrition (1994) May ; 48 (5) 326-332.

16. Semenza, G.L., Nejfelt, M.K., Chi, S.M., Antonarakis, S.E. 2003. Hypoxia-Inducible Nuclear Factors Bind to an Enhancer Element Located 3_to the Human Erythropoietin Gene. Proc Natl Acad Sci USA 88:5680-5684. 
17. Salanti, A., Dahlbäck, M., Turner, L. 2004. Evidence for the Involvement of VAR2CSA in Pregnancy-Associated Malaria. Journal of Experimental Medicine. 200(9):1197-1203.

18. Ruas, J.L., Pellinger, L., Pereira, T. 2002. Functional Analysis of Hypoxia-Inducible Factor-1 Alpha-Mediated Transsactivation. Identification of Amino Acid Residues Critical for Transcativation. Identification of Amino Acid Residues Critical for Transcriptional Activation and/or Interaction with CREB-Binding Protein. J Biol Chem 277:38723-38730.

19. Newman, P.M., Wanzira, H., Tumwine, G., Arinaitwe, E., Waldman, S., Achan, J., Havlir, D., Rosenthal, P.J., Dorsey, G., Clark, T.D., Cohan, D. 2009. Placental Malaria Among HIV-Infected and Uninfected Women Receiving Anti-Folates in a High Transmission Area of Uganda. Malaria Journal. 8:254 doi:10.1186/1475-2875-8-254.

20. Mor, G \& Abraham, V.M. 2003. Potential Role of Macrophages as Immunoregulators of Pregnancy. Reproductive Biology and Endocrinology. 1:119.

21. Hoon LJ. Artemisinin \& Its Derivatives For Antimalarial Agents. 2000. synmed.snu.ac,kr/courses/graduate/di

22. Robert A and Meunier B. Alkylating Properties Of Antimalarial Artemisinin Derivatives And Synthetic Trioxanes When Activated By Reduced Heme Model. Chem.Eur Journal, 2001; 4: 1287-1296.

23. Ludwig et al. Artemisinins Target The SERCA of Plasmodium falciparum. Nature, 2003; 424

24. Jones IW, Ley SV, Denholm AA, Lovell H, Wood A and Sinden RE. Sexual Development Of Malaria Parasites Vitro By Neem Extract And Its Semi-Synthetic Analogues. FEMS Microbiology 15, 1994.

25. Tripathi AK, Khan SI, Walker LA, Tekwani BL. Spectrophotometric Determination Of De Novo Hemozoin / $\beta$ hematin Formation An In Vitro Assay. J.Analytical Biochemistry, $2003 ; 325,85-91$.

26. Amodu OK, Adeyemo AA, Olumese PE, Ghadegesin RA. Intraleucocytic Malaria Pigment And Clinical Severity Of Malaria IChildren. The Pediatric Infectious disease Jurnal. www.pidj.com/pj/re/pidj/fulltext. 00006454-200012000-00016.htm 